\title{
Effects of the Fuel Price Increase on the Operating Cost of Freight Transport Vehicles
}

\author{
Adel Gohari ${ }^{1, *}$, Nasir Matori ${ }^{1}$, Khamaruzaman Wan Yusof ${ }^{1}$, Iraj Toloue $^{1}$, and Kin Cho \\ Myint $^{1}$ \\ ${ }^{1}$ Department of Civil and Environmental Engineering, Universiti Teknologi PETRONAS, 32610 \\ Perak, Malaysia
}

\begin{abstract}
One of the most important criteria in freight modal choices is the transport operating cost in which fuel price changes has a significant effect on it. This paper presents the impact of fuel price increases on the operating cost of the different transport modes for the containerized freight transportation. In this study, an operating cost equation was applied to compare the operating cost of different freight transport vehicles as well as evaluation of the operating cost changes across a range of fuel prices between the current price and one-hundred percent increase. The equation consists of influential parameters such as fuel cost, driver wage and maintenance cost of a vehicle. It has been concluded that the effect of the fuel price increase on the operating cost of different freight transportation modes is not in the same rate. According to equation and effective parameters considered, comparing the results showed that truck has the highest cost, train has the largest increase in price. Finally, the ship is the most influenced vehicle in terms of operating cost percentage increase when the rate of fuel price increase, followed by train and truck.
\end{abstract}

\section{Introduction}

Freight transportation is one of the backbones of any industrial system and it is a major component of the supply chain to ensure the efficient movement and timely availability of raw materials and finished products in local and international markets [1]. Freight transport is considered more censorious and critical than the past $[2,3,4,5,6]$. It involves the movement of commodities in a transport network from the origin to the destination. This movement needs infrastructures like roads, railways, waterways and airways and vehicles such as truck, train, ship and aircraft.

Freight transportation includes internal and external costs. Internal costs are the direct expenses incurred by providers of freight transportation [7]. It includes operating costs and investment in capital facilities. Energy, wages, maintenance, user charges, depreciation, and insurance are parameters that can be considered as the total operating cost. More than fifty percent of total operating cost for the transportation industry comprised of fuel price [8]. Hence, the fuel price has taken a large share in freight transportation operation cost

\footnotetext{
* Corresponding author: adel.gohari@gmail.com
} 
across all modes. The fuel price depends on variety of parameters such as international brent price, oil refining costs or import taxes, fuel marketers margins, distribution costs to deliver the refined products to the final customers, and the national petroleum taxes [9]. External costs are defined as social costs imposed on others, but not paid for, by the infrastructure user [10]. The most important external costs of transport are accidents, noise, air pollution, climate change, and congestion [11].

The contribution of this work is to determine the percentage increase of the operating costs of each transport mode based on the fuel price increase. In this study, Truck, train and ship were considered as freight transport vehicles. The operating cost equation was applied to identify the operating cost changes. This consists of three influential factors such as fuel cost, driver wage and maintenance cost of the vehicle. The average speed is assumed to be constant between origin and destination. Equal travel distance is considered for operating cost computation of all transport vehicles.

\section{Literature review}

The supply chain is a system in which different organizations, people, activities, resources and information are connected to enable movement of a specific product or service from supplier to the customer. The classic graphical overview of the supply chain is depicted in Figure 1 [12]. In this system, the integrity of the chain depends on the information flow between supplier and customer. The purpose of this process is to deliver the product in high quality and the least possible cost. A transportation chain consists of pre-haul, line-haul and end-haul parts. Pre-haul and end-haul segments mostly are carried out by road mode, while any of the road, rail, sea, air or their combinations could be considered as the transport mode for the line-haul part. The line haul transportation is represented as the central link in Figure 1.

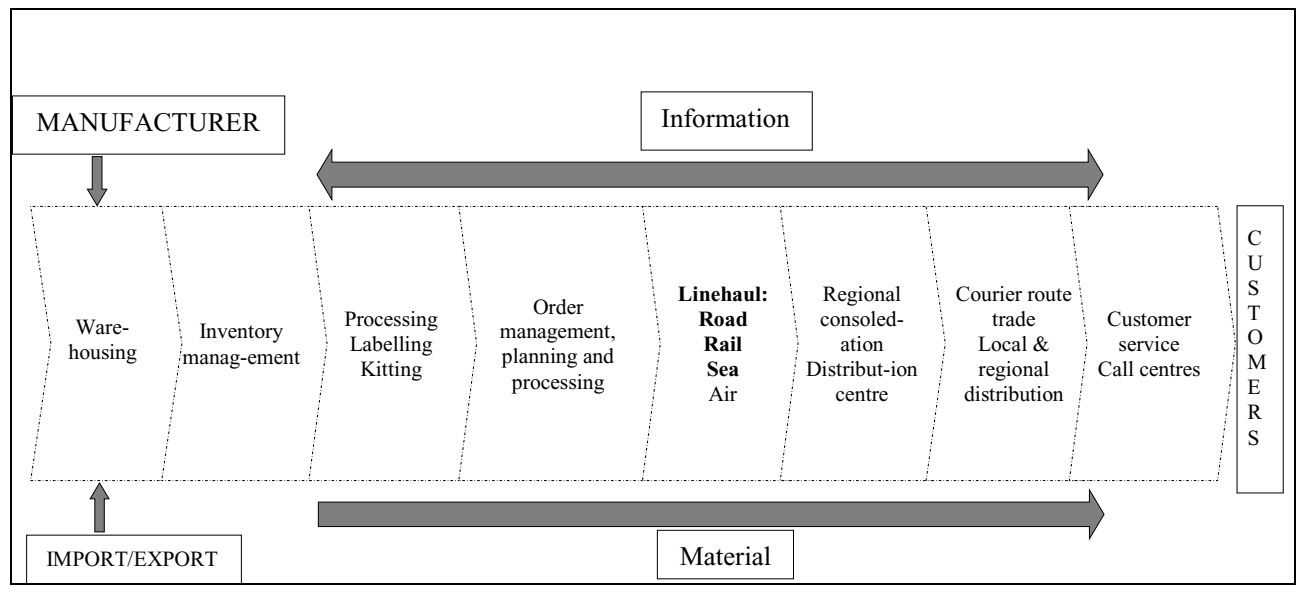

Fig. 1. A view of the supply chain.

There have been some studies related to the effect of the fuel price changes on freight transportation. A model was developed for calculating comparable combined internal and external costs of intermodal and road freight transport networks, and also conducted the sensitivity-based analysis to show the dependence of the average external, internal and full costs of the intermodal and road transport network on the door-to-door distance [13]. The impact of oil prices on U.S. domestic freight transportation was evaluated. It forecast the potential range of oil prices in the short and long terms, and then assesses how such prices 
would impact transportation logistics chains and evaluates likely changes [8]. The truck and rail demand split prediction under different West Texas Intermediate (WTI) crude oil prices estimated. When crude oil price was $50 \$ /$ barrel, the prediction for truck and train share were $68 \%$ and $32 \%$ respectively. While crude oil price changed to $\$ 200 /$ barrel, the prediction for truck and train share became $12 \%$ and $88 \%$, respectively [14]. The effects of changes in fuel prices on sea freight in Khorramshahr port examined in order to determine the effectiveness level of each factor in changes of transportation costs [15]. In spite of extensive literatures on freight transportation studies, yet a detailed and specific study about the effect of fuel price increases on operating transport cost of containers has not been investigated. The research question of this study is how many percent operating cost of each transport mode increase when fuel price increase by $100 \%$.

\section{Methodology}

In this study, five-hundred containers were considered to be moved from the origin to the destination. The distance between origin and destination was considered as one-thousand kilometres for all freight transport modes. The current diesel price in Malaysia for the truck, train and ship were considered as MYR 1.70, 1.75 and 1.55 per litre, respectively. Fuel consumption for truck, train and ship were considered as $0.193,4.25$ and 51.476 litres per kilometre respectively [16]. Driver wage is on an hourly basis and it varies for different modes of transport. Maintenance cost of transport vehicles was considered per kilometre of travel. Assumed capacity for truck, train and ship were 2, 40 and 500 TEUs per vehicle, respectively. TEU is the twenty-foot equivalent unit and one TEU indicates one 20 -foot ISO-standard intermodal container [17]. The average speed for truck, train and ship were assumed as 90,60 and 30 kilometres per hour respectively. The Capacity of vehicles was considered on the basis of the number of TEUs that each one of them can carry. Total operating cost $(T C)$ was calculated using the Equation 1.

$$
T C=[(F p \times F c \times T d)+(W a \times T t)+(M a \times T d)] \times[N c / C v]
$$

where $T C, F p, F c$, and Td are transport cost (MYR), fuel price (RM/liter), and fuel consumption (liter $/ \mathrm{km})$, travel distance $(\mathrm{Km})$, respectively. $\mathrm{Wa}, \mathrm{Tt}, \mathrm{Ma}, \mathrm{Nc}$, and $\mathrm{Cv}$ represent wage $(\mathrm{RM} / \mathrm{h})$, travel time $(\mathrm{h})$, maintenance $(\mathrm{RM} / \mathrm{Km})$, the number of containers, and capacity of the vehicle (TEU) consequently.

\section{Results and discussions}

The result of operating cost calculation for each transportation mode are depicted in Tables 1-3, and their related graphs are shown in Fig. 2. The operating costs were calculated based on current diesel price, $20 \%, 40 \%, 60 \%, 80 \%$ and $100 \%$ price increase for all freight transport vehicles. In the aforementioned tables, the cost of one vehicle, total cost and cost per TEU were calculated. The cost of one vehicle is related to the generated transport cost for the movement of a number of containers according to the capacity of each type of vehicle from the origin to the destination. The total cost is referred to the cost for the shipment of all containers according to a number of necessary certain vehicles. The cost per TEU indicates the cost for the movement of one container from the source to the destination. Comparing Tables 1-3 indicated that freight transport by truck was more expensive than the train and ship. According to current fuel price, operating cost of one container movement by truck was RM 702.93, while cost for train and ship were MYR 292.18 and MYR 181.57 respectively. Also, when fuel price changed to two times more 
expensive than the current price, operating cost per container by train was increased to RM 185.93, and truck and ship cost increased to RM 164.05 and 159.57 respectively. Fig. 2 show the relationship between fuel price as the independent variable and operating cost per TEU as the dependent variable for the truck, train and ship, respectively. These relationships for all transport vehicles were linear. The changes of operating cost of transport in percentage for different modes of transport against percentage of fuel price increase were compared and showed in Fig. 5.

Table 1. Operating cost of truck across fuel price increase.

\begin{tabular}{|c|c|c|c|c|c|}
\hline $\begin{array}{c}\text { Fuel } \\
\text { Price } \\
(\mathrm{RM} / \mathrm{L})\end{array}$ & $\begin{array}{c}\text { Wage } \\
(\mathrm{RM} / \mathrm{H})\end{array}$ & $\begin{array}{c}\text { Maintenance } \\
(\mathrm{RM} / \mathrm{Km})\end{array}$ & $\begin{array}{c}\text { Cost of one } \\
\text { Vehicle } \\
(\mathrm{RM})\end{array}$ & $\begin{array}{c}\text { Total Cost } \\
(\mathrm{RM})\end{array}$ & $\begin{array}{c}\text { Cost/TEU } \\
(\mathrm{RM})\end{array}$ \\
\hline 1.70 & 7 & 1 & 1405.87 & 351469.44 & 702.93 \\
\hline 2.04 & 7 & 1 & 1471.49 & 367874.44 & 735.74 \\
\hline 2.38 & 7 & 1 & 1537.11 & 384279.44 & 768.55 \\
\hline 2.72 & 7 & 1 & 1602.73 & 400684.44 & 801.36 \\
\hline 3.06 & 7 & 1 & 1668.35 & 417089.44 & 834.17 \\
\hline 3.40 & 7 & 1 & 1733.97 & 433494.44 & 866.98 \\
\hline
\end{tabular}

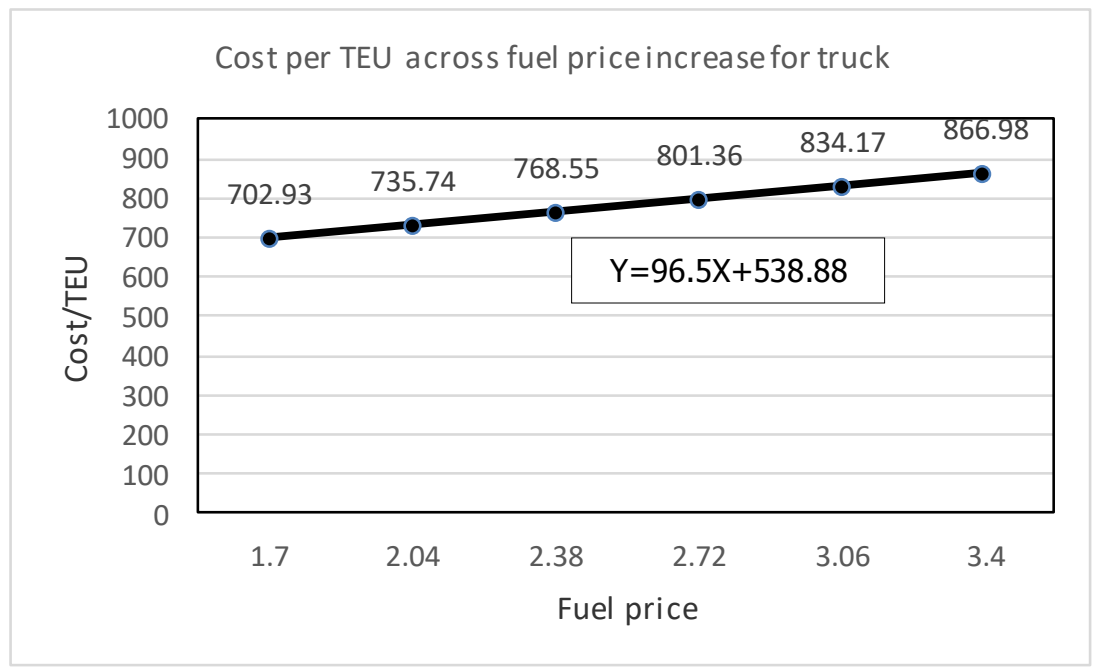

Fig. 2. Cost per TEU across fuel price increase for truck.

Table 2. Operating cost of train across fuel price increase 


\begin{tabular}{|c|c|c|c|c|c|}
\hline $\begin{array}{c}\text { Fuel } \\
\text { Price } \\
(\mathrm{RM} / \mathrm{L})\end{array}$ & $\begin{array}{c}\text { Wage } \\
(\mathrm{RM} / \mathrm{H})\end{array}$ & $\begin{array}{c}\text { Maintenance } \\
(\mathrm{RM} / \mathrm{Km})\end{array}$ & $\begin{array}{c}\text { Cost of one } \\
\text { Vehicle } \\
(\mathrm{RM})\end{array}$ & $\begin{array}{c}\text { Total Cost } \\
(\mathrm{RM})\end{array}$ & $\begin{array}{c}\text { Cost/TEU } \\
(\mathrm{RM})\end{array}$ \\
\hline 1.75 & 15 & 4 & 11687.5 & 146093.75 & 292.18 \\
\hline 2.10 & 15 & 4 & 13175.0 & 164687.50 & 329.37 \\
\hline 2.45 & 15 & 4 & 14662.5 & 183281.25 & 366.56 \\
\hline 2.80 & 15 & 4 & 16150.0 & 201875.00 & 403.75 \\
\hline 3.15 & 15 & 4 & 17637.5 & 220468.75 & 440.93 \\
\hline 3.50 & 15 & 4 & 19125.0 & 239062.50 & 478.12 \\
\hline
\end{tabular}

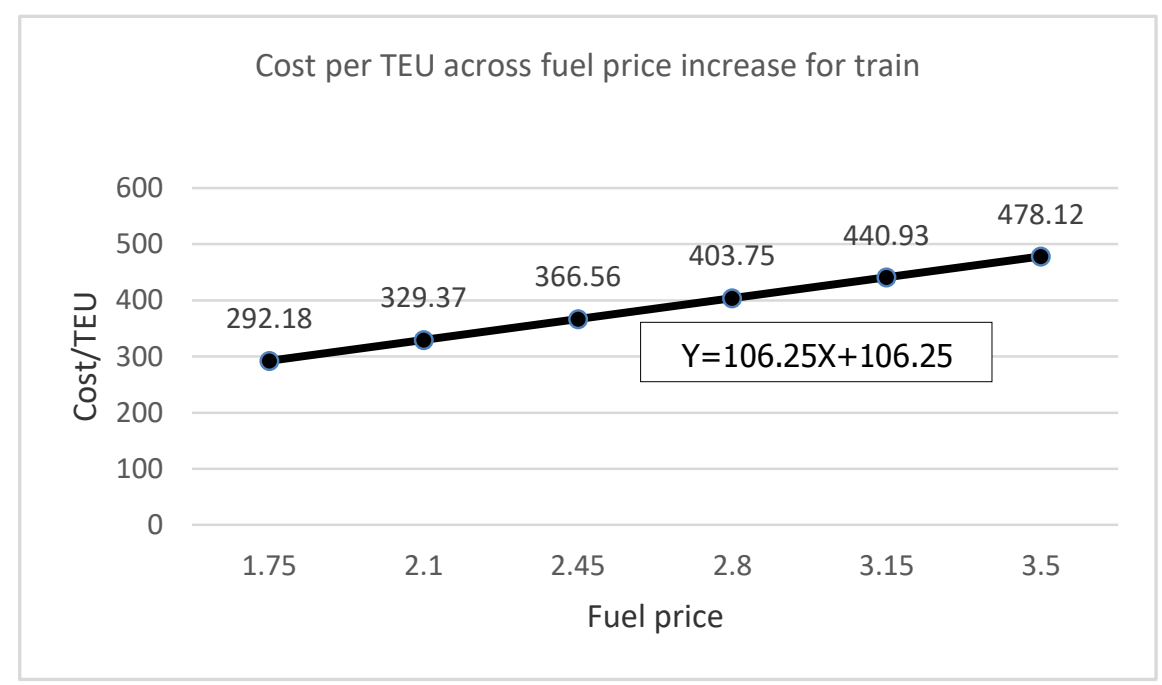

Fig. 3. Cost per TEU across fuel price increase for train.

Table 3. Operating cost of ship across fuel price increase

\begin{tabular}{|c|c|c|c|c|c|}
\hline $\begin{array}{c}\text { Fuel } \\
\text { Price } \\
(\mathrm{RM} / \mathrm{L})\end{array}$ & $\begin{array}{c}\text { Wage } \\
(\mathrm{RM} / \mathrm{H})\end{array}$ & $\begin{array}{c}\text { Maintenance } \\
(\mathrm{RM} / \mathrm{Km})\end{array}$ & $\begin{array}{c}\text { Cost of } \\
\text { one } \\
\text { Vehicle } \\
(\mathrm{RM})\end{array}$ & $\begin{array}{c}\text { Total Cost } \\
(\mathrm{RM})\end{array}$ & $\begin{array}{c}\text { Cost/TEU } \\
(\mathrm{RM})\end{array}$ \\
\hline 1.55 & 30 & 10 & 90787.80 & 90787.80 & 181.57 \\
\hline 1.86 & 30 & 10 & 106745.36 & 106745.36 & 213.49 \\
\hline 2.17 & 30 & 10 & 122702.92 & 122702.92 & 245.40 \\
\hline 2.48 & 30 & 10 & 138660.48 & 138660.48 & 277.32 \\
\hline 2.79 & 30 & 10 & 154618.04 & 154618.04 & 309.23 \\
\hline 3.10 & 30 & 10 & 170575.60 & 170575.60 & 341.15 \\
\hline
\end{tabular}




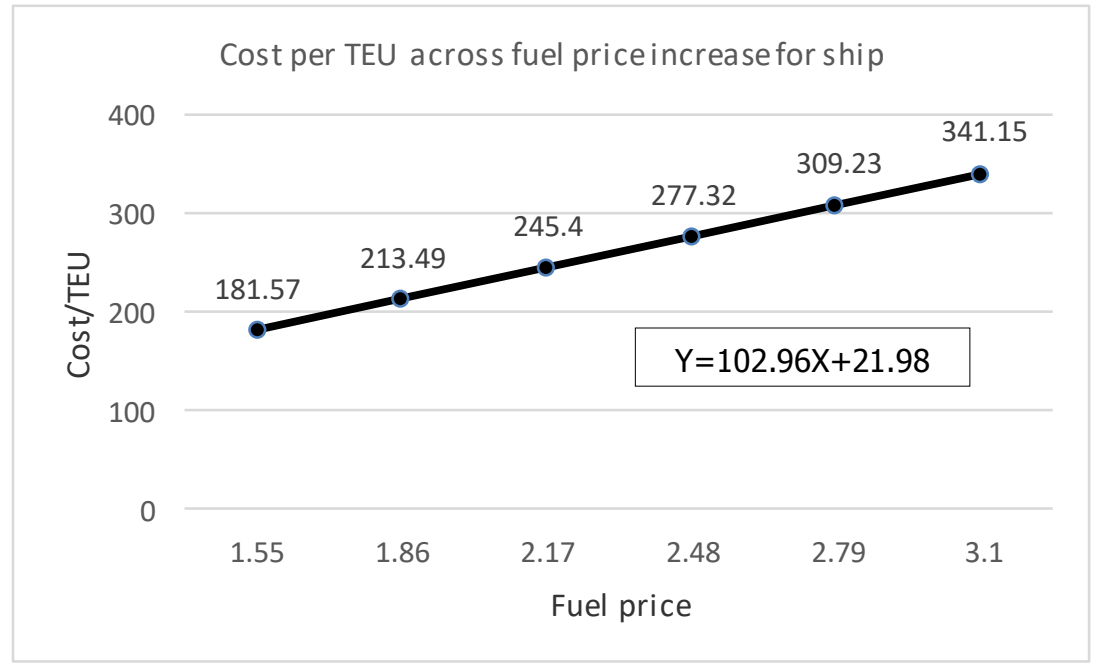

Fig. 4. Cost per TEU across fuel price increase for ship.

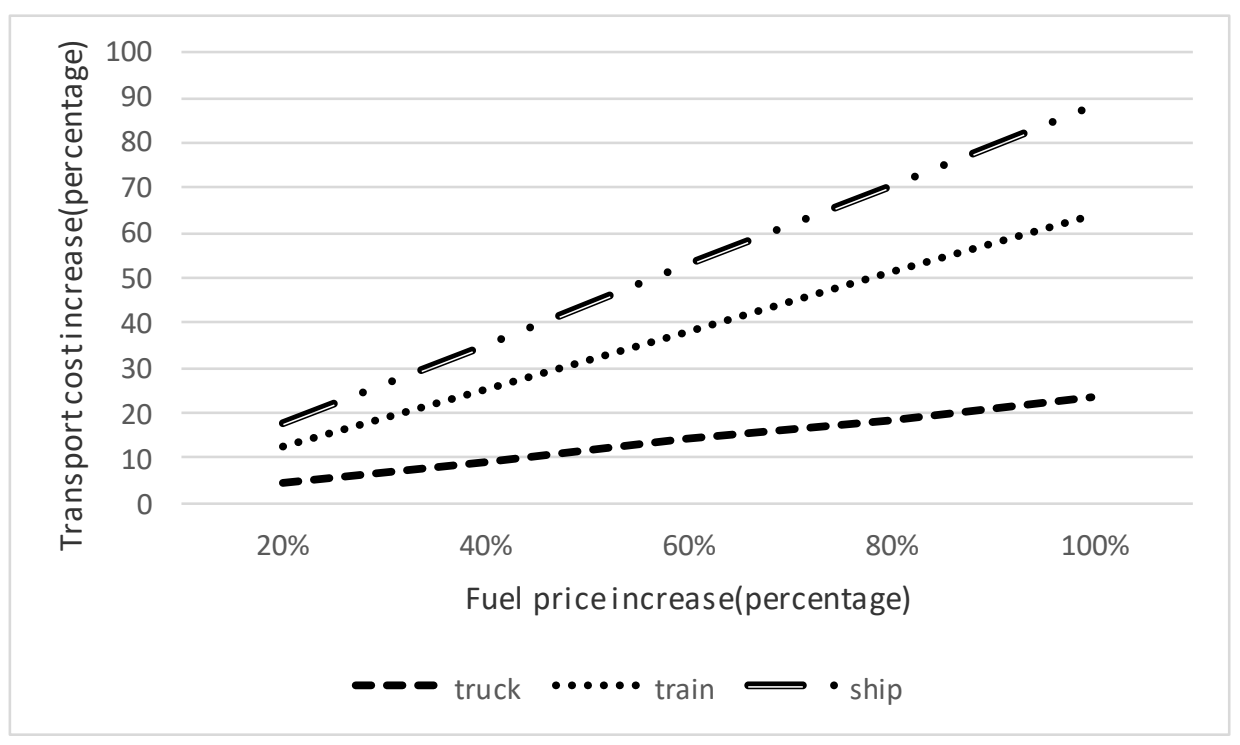

Fig. 5. Comparison of cost of transport modes against fuel price increase.

\section{Conclusions}

In this paper, the operating cost equation of freight transport was used to evaluate transport cost of freight container across fuel price percentage increase for truck, train and ship. Based on the operating cost equation and assumptions considered in this study, the following can be concluded. The truck was the most expensive vehicle and its cost per TEU was about 2.5 times more than the train and almost more than four times compared to the ship. Moreover, there was linear relationship between fuel price and the operating cost for different freight transport vehicles. The highest operating cost increase was related to train and followed by truck and ship. The rate of fuel price increase has the most significant effect on the operating cost of the ship. The operating cost of the ship increased by $87.8 \%$ 
when fuel price increases by $100 \%$. Whereas, for train and truck, $100 \%$ fuel price increases led to an increment in operating cost by about $63.6 \%$ and $23.3 \%$ respectively.

\section{References}

1. T.G, Crainic, Handbook of Transportation Science, Springer US, (2003).

2. E. Kreutzberger, C., Macharis, L., Vereecken, J., Woxenius, Nectar Conference 7 (2003).

3. T.R. Lakshmanan, X., Han, Transportation Research Part D: Transport and Environment 2, 1-5 (1997).

4. P.J., Marcotullio, E., Williams, J.D., Marshall, The Journal of Environment \& Development 14, 125-48 (2005).

5. A.M., Hricko, Environmental Health Perspectives, 114, 204-205 (2006).

6. J., Léonardi, M., Baumgartner, Transportation Research Part D: Transport and Environment 9, 451-64 (2004).

7. A., Ricci, I., Black, Research In Transportation Economics 14, 245-85 (2005).

8. Transportation Economics and Management Systems (TEMS), Maritime Administration, Department of Transportation (2008).

9. C. Macharis, E., Van Hoeck, E., Pekin, T., Van Lier, Transportation Research Part A: Policy And Practice 44, 550-61 (2010).

10. Danish Ministry of Transport, Review of European Studies (2004).

11. C. Schreyer, C., Schneider, M., Maibach, W., Rottengatter, C., Doll, D., Schmedding, Final report, INFRAS/IWW, Zurich (2004).

12. Economic and Social Commission for Asia and the Pacific (ESCAP), Review of Developments in Transport and Communications in the ESCAP Region 1996-2001, New York, (2001).

13. M., Janic, Transportation Research Part D: Transport and Environment 12, 33-44 (2007).

14. T., Hwang, Y., Ouyang, Journal Of The Air \& Waste Management Association 64, 212 (2014).

15. R.D., Bahmanshir, M.A., Falahi, Advances in Management and Applied Economics 5, 87 (2015).

16. P.D., Cenek, R.J., Kean, I.A., Kvatch, N.J., Jamieson, NZ Transport Agency Research Report 497, Wellington, Oct. (2012).

17. P., Brodie, Dictionary of Shipping Terms, ed. 2, Lloyd's of London Press LTD (1994). 